Portland Cement Paste and Concrete 
Also from The Macmillan Press:

CIVIL ENGINEERING MATERIALS

Edited by N. Jackson

REINFORCED CONCRETE DESIGN

W. H. Mosley and J. H. Bungey 


\section{Portland Cement Paste and Concrete}

\section{Soroka}

Professor, Building Research Station, Faculty of Civil Engineering, Technion-Israel Institute of Technology, Haifa, Israel 
(c) I. Soroka 1979

Softcover reprint of the hardcover 1st edition 1979

All rights reserved. No part of this publication may be

reproduced or transmitted, in any form or by any means, without permission

First published 1979 by

THE MACMILLAN PRESS LTD

London and Basingstoke

Associated companies in Delhi Dublin

Hong Kong Johannesburg Lagos Melbourne

New York Singapore and Tokyo

Typeset by

Reproduction Drawings Ltd, Sutton, Surrey

British Library Cataloguing in Publication Data

Soroka, Itzhak

Portland cement paste and concrete.

1. Concrete 2. Portland cement

I. Title

$666^{\prime} .89 \quad$ TA439

ISBN 978-1-349-03996-8 ISBN 978-1-349-03994-4 (eBook)

DOI 10.1007/978-1-349-03994-4

This book is sold subject to the standard conditions of the Net Book Agreement 


\section{Contents}

Preface xii

Acknowledgements xiii

1 Chemical and mineralogical composition 1

1.1 Introduction 1

1.2 Chemical composition 1

1.3 Mineralogical composition: major constituents 3

1.4 Properties of the major constituents 7

1.4.1 Tricalcium silicate $\left(\mathrm{C}_{3} \mathrm{~S}\right) \quad 7$

1.4.2 Dicalcium silicate $\left(\mathrm{C}_{2} \mathrm{~S}\right) \quad 9$

$\begin{array}{lll}1.4 .3 & \text { Tricalcium aluminate }\left(\mathrm{C}_{3} \mathrm{~A}\right) & 10\end{array}$

1.4.4 Tetracalcium aluminoferrite $\left(\mathrm{C}_{4} \mathrm{AF}\right) \quad 10$

$\begin{array}{lll}1.4 .5 & \text { Summary } & 10\end{array}$

$\begin{array}{lll}1.5 & \text { Minor constituents } & 10\end{array}$

1.5.1 Gypsum $\left(\mathrm{CaSO}_{4} \cdot 2 \mathrm{H}_{2} \mathrm{O}\right) \quad 10$

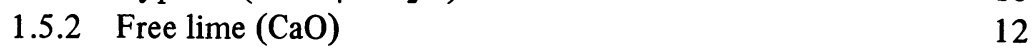

$\begin{array}{lll}1.5 .3 & \text { Magnesia }(\mathrm{MgO}) & 15\end{array}$

1.5.4 Alkali oxides $\left(\mathrm{Na}_{2} \mathrm{O}, \mathrm{K}_{2} \mathrm{O}\right) \quad 15$

$\begin{array}{lll}1.5 .5 & \text { Titanium oxide }\left(\mathrm{TiO}_{2}\right) & 16\end{array}$

1.5.6 Phosphorus pentoxide $\left(\mathrm{P}_{2} \mathrm{O}_{5}\right) \quad 16$

1.6 Potential compound composition by the Bogue method 16

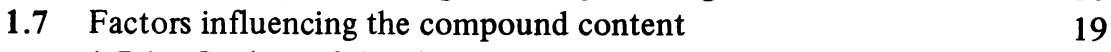

$\begin{array}{ll}\text { 1.7.1 Cooling of the clinker } & 19\end{array}$

1.7.2 Composition of the ferrite phase 20

1.7.3 Composition of major compounds 21

1.8 Determination of compound composition by direct methods 23

1.8.1 Optical microscopy 23

1.8.2 X-Ray diffraction 24

1.9 Summary and concluding remarks 25

1.10 References 25

2 Setting and hardening 28

2.1 Introduction 28 
2.2 Hydration of the cement

2.2.1 Calcium silicates $\left(\mathrm{C}_{2} \mathrm{~S}\right.$ and $\left.\mathrm{C}_{3} \mathrm{~S}\right) \quad 31$

$\begin{array}{lll}2.2 .2 & \text { Tricalcium aluminate }\left(\mathrm{C}_{3} \mathrm{~A}\right) & 32\end{array}$

$\begin{array}{lll}2.2 .3 & \text { Ferrite phase } & 34\end{array}$

2.3 Development of structure in cement paste 34

2.4 Factors affecting the rate of hydration 36

$\begin{array}{lll}2.4 .1 & \text { Age of paste } & 36\end{array}$

$\begin{array}{lll}2.4 .2 & \text { Cement composition } & 38\end{array}$

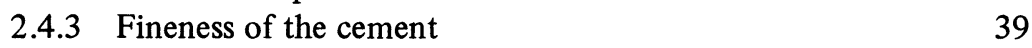

$\begin{array}{lll}2.4 .4 & \text { Water/cement ratio } & 39\end{array}$

$\begin{array}{lll}2.4 .5 & \text { Temperature } & 40\end{array}$

2.4.6 Admixtures $\quad 42$

2.5 Summary and concluding remarks 43

$\begin{array}{lll}2.6 & \text { References } & 44\end{array}$

3 Structure of the hardened paste 46

$\begin{array}{lll}3.1 & \text { Introduction } & 46\end{array}$

3.2 Adsorption isotherms and the BET method 46

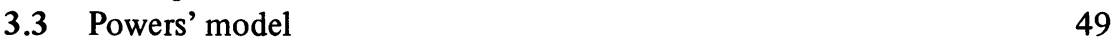

3.3.1 Water in the hardened paste $\quad 50$

3.3.2 Adsorption isotherms for cement pastes $\quad 52$

3.3.3 Specific surface area of hydration products $\quad 56$

3.3.4 Size of gel pores $\quad 58$

3.3.5 Density of the hydration products $\quad 59$

3.3.6 Specific volume of combined water-intrinsic shrinkage $\quad 60$

$\begin{array}{lll}3.3 .7 & \text { Porosity of the gel } & 60\end{array}$

$\begin{array}{ll}\text { 3.3.8 Gel to cement volume ratio } & 61\end{array}$

$\begin{array}{ll}\text { 3.3.9 Size of gel particles } & 61\end{array}$

3.3.10 Summary of Powers' model $\quad 62$

$\begin{array}{lll}3.4 & \text { Ishai's model } & 62\end{array}$

3.5 Feldman and Sereda's model 64

$\begin{array}{lll}3.5 .1 & \text { General considerations } & 65\end{array}$

3.5.2 Separation of different types of water held in the paste 67

$\begin{array}{ll}\text { 3.5.3 Specific surface area from nitrogen adsorption } & 68\end{array}$

3.5.4 Summary of Feldman and Sereda's model 69

$\begin{array}{ll}\text { 3.6 Summary and concluding remarks } & 70\end{array}$

$\begin{array}{lll}3.7 & \text { References } & 71\end{array}$

4 Strength of the hardened paste 73

$\begin{array}{lll}\text { 4.1 Bond between gel particles } & 73\end{array}$

$\begin{array}{lll}4.2 & \text { Failure mechanism } & 76\end{array}$ 
$\begin{array}{lll}4.3 & \text { Factors affecting strength } & 81\end{array}$

$\begin{array}{lll}\text { 4.3.1 Porosity } & 81\end{array}$

4.3.2 Water/cement ratio $\quad 85$

$\begin{array}{ll}\text { 4.3.3 Degree of hydration } & 87\end{array}$

$\begin{array}{lll}\text { 4.3.4 Temperature } & 90\end{array}$

4.3.5 Temperature combined with pressure

$\begin{array}{ll}\text { 4.3.6 Moisture content } & 97\end{array}$

4.4 Summary and concluding remarks 98

4.5 References 99

5 Volume changes in the hardened paste 102

$\begin{array}{lll}5.1 & \text { Introduction } & 102\end{array}$

$\begin{array}{ll}5.2 & \text { Elastic volume changes } \\ & 102\end{array}$

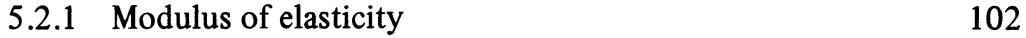

5.2.2 Poisson's ratio 106

5.3 Shrinkage and swelling 106

5.3.1 Introduction and definitions 106

$\begin{array}{ll}\text { 5.3.2 Factors affecting shrinkage } & 109\end{array}$

5.3.2.1 $W / C$ ratio 109

5.3.2.2 Degree of hydration $\quad 112$

5.3.2.3 Porosity of the paste 112

5.3.2.4 Autoclave treatment 113

5.3.2.5 Admixtures $\quad 114$

$\begin{array}{ll}\text { 5.3.3 Shrinkage and swelling mechanisms } & 114\end{array}$

5.3.3.1 Capillary tension $\quad 115$

5.3.3.2 Surface tension (surface energy) 118

5.3.3.3 Swelling pressure 121

5.3.3.4 Movement of interlayer water 122

5.3.4 Mechanism of irreversible shrinkage 123

5.3.5 Summary and concluding remarks about

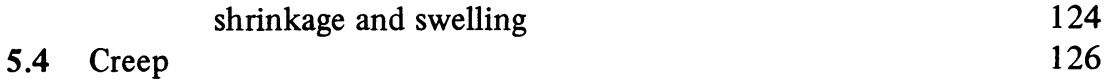

$\begin{array}{ll}\text { 5.4.1 Introduction and definitions } & 126\end{array}$

$\begin{array}{ll}\text { 5.4.2 Factors affecting creep } & 128\end{array}$

5.4.2.1 Drying conditions 128

5.4.2.2 Strength of paste 129

5.4.2.3 Temperature 130

5.4.2.4 Stress level and stress/strength ratio $\quad 130$

5.4.2.5 Moisture content 131

5.4.2.6 Admixtures 132 
5.4.3 Creep mechanism

5.4.3.2 Glucklich and Ishai's model 133

5.4.3.3 Feldman and Sereda's model 134

5.4.3.4 Munich model 134

5.4.4 Summary and concluding remarks about creep 135

5.5 Carbonation shrinkage 136

5.6 Thermal volume changes 139

5.7 References 141

6 Chemical and frost resistance of hardened cement paste $\quad 145$

6.1 Introduction 145

6.2 Permeability and absorption 146

6.3 Chemical resistance 149

$\begin{array}{ll}\text { 6.3.1 Dissolution and leaching in soft water } & 149\end{array}$

$\begin{array}{lr}\text { 6.3.2 Acids and acidic solutions } & 150\end{array}$

6.3.3 Sulphate solutions 151

$\begin{array}{lll}\text { 6.3.4 Sea water } & 154\end{array}$

6.3.5 Summary and concluding remarks about chemical
resistance

6.4 Frost resistance 156

6.4.1 Introduction 156

6.4.2 Mechanism of frost action 157

6.4.2.1 Hydraulic pressure $\quad 157$

6.4.2.2 Growth of capillary ice 158

6.4.2.3 Osmotic pressure 161

6.4.2.4 Diffusion due to decreasing relative humidity 162

6.4.3 Factors affecting frost resistance of cement pastes 163

6.4.3.1 Moisture content 163

6.4.3.2 Water/cement ratio 164

6.4.3.3 Air content 165

6.4.4 Summary and concluding remarks about frost resistance 166

6.5 References 167

7 Effect of cement composition and fineness on its properties $\quad 169$

$\begin{array}{lll}7.1 & \text { Introduction } & 169\end{array}$

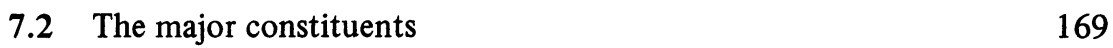

7.2.1 Effect on heat of hydration $\quad 169$

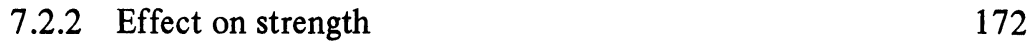

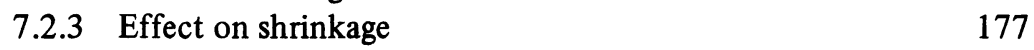

$\begin{array}{ll}\text { 7.2.4 Effect on sulphate resistance } & 177\end{array}$ 
$\begin{array}{ll}\text { 7.3 The minor constituents } & 179\end{array}$

$\begin{array}{lll}\text { 7.3.1 Effect of gypsum } & 179\end{array}$

7.3.2 Effect of alkalis and trace elements 179

$\begin{array}{lll}7.4 & \text { Effect of specific surface area } & 179\end{array}$

$\begin{array}{lll}\text { 7.4.1 Fineness } & 179\end{array}$

7.4.2 Determination of specific surface area $\quad 180$

$\begin{array}{ll}\text { 7.4.2.1 Air-permeability method } & 180\end{array}$

7.4.2.2 Turbidimetric method 182

7.4.2.3 Gas adsorption $\quad 183$

$\begin{array}{lll}\text { 7.4.3 Effect on strength } & 183\end{array}$

$\begin{array}{ll}\text { 7.4.4 Effect on drying shrinkage } & 184\end{array}$

$\begin{array}{ll}\text { 7.4.5 Other effects } & 185\end{array}$

7.5 Summary-different types of Portland cement 185

$\begin{array}{ll}\text { 7.5.1 Rapid-hardening cement } & 187\end{array}$

$\begin{array}{ll}\text { 7.5.2 Low-heat cement } & 190\end{array}$

$\begin{array}{ll}\text { 7.5.3 Sulphate resisting cement } & 190\end{array}$

$\begin{array}{ll}\text { 7.5.4 White cement } & 191\end{array}$

$\begin{array}{lll}7.6 & \text { References } & 191\end{array}$

8 Strength of concrete 194

8.1 Failure mechanism 194

8.2 Paste-aggregate bond 197

$\begin{array}{lll}\text { 8.2.1 Water/cement ratio } & 197\end{array}$

$\begin{array}{ll}\text { 8.2.2 Surface roughness of aggregate } & 197\end{array}$

8.2.3 Chemical composition 198

8.2.4 Effect of paste-aggregate bond on concrete strength 199

8.3 Effect of aggregate properties on concrete strength 201

$\begin{array}{ll}\text { 8.3.1 Strength } & 201\end{array}$

$\begin{array}{ll}\text { 8.3.2 Modulus of elasticity } & 202\end{array}$

$\begin{array}{lll}\text { 8.3.3 Particle size } & 202\end{array}$

8.3.4 Concentration 203

8.3.5 Summary of aggregate properties 205

8.4 Effect of $W / C$ ratio on concrete strength-Abrams' law 205

8.5 Effect of temperature on strength 208

8.6 Factors affecting the results of strength tests 211

8.6.1 Compressive strength 211

8.6.1.1 End conditions and capping 212

8.6.1.2 Shape and dimensions of the test specimen 214

$\begin{array}{ll}\text { 8.6.1.3 Loading rate } & 217\end{array}$

$\begin{array}{lll}\text { 8.6.2 Tensile strength } & 218\end{array}$

8.6.2.1 Flexural strength 218

$\begin{array}{ll}\text { 8.6.2.2 Splitting test } 220 & 218\end{array}$ 
$\begin{array}{ll}\text { 8.7 Summary and concluding remarks } & 221\end{array}$

$\begin{array}{lll}8.8 & \text { References } & 223\end{array}$

9 Volume changes in hardened concrete $\quad 227$

$\begin{array}{lll}9.1 & \text { Introduction } & 227\end{array}$

$\begin{array}{lll}9.2 & \text { Stress-strain curve } & 227\end{array}$

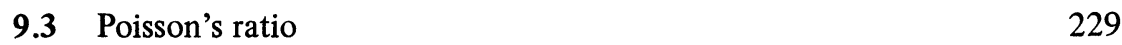

$\begin{array}{lll}9.4 & \text { Modulus of elasticity } & 232\end{array}$

9.4.1 Effect of properties of the aggregate 233

$\begin{array}{lll}\text { 9.4.2 Effect of concrete strength } & 237\end{array}$

9.4.3 Determination of modulus of elasticity 239

9.4.3.1 Loading tests 239

9.4.3.2 Electrodynamic determination $\quad 239$

9.4.3.3 Ultrasonic pulse method 241

$\begin{array}{lll}9.5 & \text { Drying shrinkage } & 242\end{array}$

9.5.1 Effect of properties of the aggregate 242

$\begin{array}{ll}\text { 9.5.2 Shrinkage-induced cracking } & 245\end{array}$

9.5.3 Summary and quantitative estimate of shrinkage 248

$\begin{array}{lll}9.6 & \text { Creep } & 250\end{array}$

9.6.1 Effect of properties of the aggregate 250

$\begin{array}{ll}\text { 9.6.2 Quantitative estimates } & 253\end{array}$

9.6.3 Summary and concluding remarks about creep 255

9.7 Volume changes due to thermal expansion 256

$\begin{array}{lll}9.8 & \text { References } & 257\end{array}$

10 Durability of concrete $\quad 260$

$\begin{array}{ll}10.1 \text { Introduction } & 260\end{array}$

10.2 Concrete in ground-water or soils containing sulphate salts 261

$\begin{array}{ll}\text { 10.2.1 Classification of aggressiveness } & 261\end{array}$

10.2.2 Factors affecting sulphate resistance $\quad 264$

$\begin{array}{ll}\text { 10.2.3 Tests for sulphate resistance } & 268\end{array}$

$\begin{array}{ll}10.3 \text { Concrete in sea water } & 268\end{array}$

$\begin{array}{ll}10.4 \text { Concrete in acidic environments } & 269\end{array}$

$\begin{array}{ll}10.5 \text { Frost resistance } & 271\end{array}$

$\begin{array}{ll}\text { 10.5.1 Effect of } W / C \text { ratio } & 271\end{array}$

10.5.2 Effect of concrete strength $\quad 272$

10.5.3 Effect of air-entrainment $\quad 275$

10.5.4 Effect of aggregate quality 276

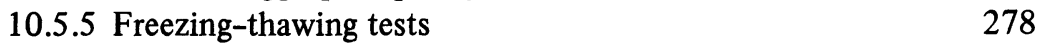

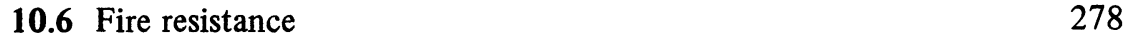

$\begin{array}{ll}10.7 \text { Abrasion resistance } & 280\end{array}$ 
10.8 Summary and concluding remarks

10.8.1 Concrete in sulphate-containing soils and solutions

10.8.2 Concrete in sea water

10.8.3 Concrete in acidic solutions 285

10.8.4 Frost resistance 285

10.8.5 Fire resistance 285

10.8.6 Abrasion resistance $\quad 285$

10.8.7 Overall durability 288

10.9 References

11 Effect of technical factors on properties of concrete

11.1 Introduction

11.2 Mix proportions 292

11.3 Batching 293

$\begin{array}{ll}11.4 \text { Mixing } & 294\end{array}$

$\begin{array}{ll}11.5 \text { Segregation } & 296\end{array}$

11.6 Consolidation 297

11.7 Curing 298

11.7.1 Steam-curing under atmospheric pressure 301

11.7.1.1 Effect on strength $\quad 303$

(a) Initial strength 303

(b) Later-age strength 307

(c) Prediction of strength 311

11.7.1.2 Effect on drying-shrinkage $\quad 312$

11.7.1.3 Effect on creep $\quad 314$

11.7.1.4 Effect on permeability $\quad 315$

11.7.1.5 Effect on sulphate resistance 315

11.7.2 Steam-curing under pressure (autoclave treatment) $\quad 316$

11.7.2.1 Effect on strength $\quad 316$

11.7.2.2 Effect on drying-shrinkage and creep $\quad 317$

11.7.2.3 Effect on sulphate resistance 318

$\begin{array}{ll}11.8 \text { Summary and concluding remarks } & 318\end{array}$

$\begin{array}{ll}\text { 11.8.1 Mix proportions } & 318\end{array}$

$\begin{array}{ll}\text { 11.8.2 Batching } & 319\end{array}$

$\begin{array}{ll}11.8 .3 \text { Mixing } & 319\end{array}$

$\begin{array}{ll}11.8 .4 \text { Segregation } & 319\end{array}$

$\begin{array}{ll}\text { 11.8.5 Consolidation } & 319\end{array}$

$\begin{array}{ll}11.8 .6 \text { Curing } & 319\end{array}$

11.8.7 Steam-curing under atmospheric pressure 319

11.8.8 Steam-curing under pressure (autoclave treatment) $\quad 320$

$\begin{array}{ll}11.9 \text { References } & 320\end{array}$

Name index $\quad 323$

Subject index 331 


\section{Preface}

This book describes and explains the properties and behaviour of Portland cement paste and concrete with respect to their composition and physical structure. The intention is to provide civil and structural engineers, architects and other users of concrete with a better insight into these aspects, and consequently to help them to understand and cope with practical problems which may arise in the daily use of concrete. In addition, the book is intended for use as an advanced textbook on cement and concrete for students of civil engineering or architecture.

First, Portland cement is discussed with particular reference to the effect of its composition and some manufacturing factors on its properties, and the resultant properties of the paste and concrete. Then the hydration process and structure formation of the hardened paste are described, and the factors affecting these processes are explained. The physical structure of the hardened paste is presented in some detail together with the suggested models. The properties of the hardened paste and its behaviour are explained with respect to these models. Finally, concrete properties and behaviour are dealt with at some length. Essentially this is done by considering the effect of the aggregate on the properties of the paste. The effect of some technical factors on the properties of concrete are briefly considered with some emphasis on the effect of steam curing and autoclave treatment.

A number of topics included in this book are usually dealt with in some detail in publications addressed to non-engineers, such as chemists, physicists, etc., and have hitherto only been partially discussed in the available books on concrete. The book, although not claiming to be comprehensive, tries to provide a systematic and comprehensive treatment of these topics in terms which are familiar to its potential readers, namely, civil and structural engineers, architects, etc. It is believed that, in this respect, and in its more basic treatment of the subject, the book differs from apparently similar books. 


\section{Acknowledgements}

A substantial part of this book was written during the academic year 1975/6, when the author, on sabbatical leave from the Technion-Israel Institute of Technology, was a guest Professor at the Department of Civil Engineering and Building Technology, the University of Wales Institute of Science and Technology (UWIST), Cardiff. He is indebted to Professor J. D. Geddes BSc, PhD, FICE, FASCE, MIHE, FGS, FIOB, Head of the Department, and to the members of his staff, for their kind help and hospitality.

The author would like to thank his colleagues, Professor J. Glucklich and Dr D. Ravina of the Technion's Faculty of Civil Engineering, for reading through parts of the original manuscript and for their helpful comments and remarks. Also to be thanked are Mrs S. Eagle for typing the manuscript and Mrs N. Arad for producing the artwork.

The book includes numerous figures and tables which were originally published by others elsewhere. The author is indebted to the relevant institutions, journals, etc. for permission to reproduce the following figures and tables:

The American Ceramic Society, 65 Ceramic Drive, Columbus, Ohio 43214, USA (Figures 4.1, 4.8, 4.9, 6.2, 6.9 and 6.10).

American Concrete Institute (ACI), P.O.B. 19150, Detroit, Michigan 48219, USA (Figures 3.3 to $3.9,4.15,4.22,4.23,5.14,6.3,7.10,8.2,8.7,8.9$, $8.11,8.17,9.3,9.5,9.16,9.17,9.25,9.26,10.6,11.3,11.4,11.7,11.22$, 11.25 and Table 10.5.

American Society of Civil Engineers, 345 East 47th Street, New York, NY 10017, USA (Figures 6.3 and 6.4).

American Society for Testing and Materials (ASTM), 1916 Race St, Philadelphia, Pennsylvania 19103, USA (Figures 7.13, 8.15, 8.18, 8.21 and 10.7 to 10.9$)$.

Applied Science Publishers Ltd, Rippleside Commercial Estate, Barking, Essex, UK (Figure 9.11). 
British Standards Institution, 2 Park St, London W1 A 2BS, UK (Figures 2.2 and 7.8, and Tables 9.1 and 10.1).

Building Research Station, Technion-Israel Institute of Technology, Technion City, Haifa, Israel (Figures 3.15, 9.23, 9.24, 10.10, 10.11, 11.1, 11.2, $11.17,11.20$ and 11.21).

Bureau of Reclamation, United States Department of Interior, P.O.B. 25007, Building 67, Denver Federal Center, Denver, Colorado, 80225, USA (Figures 7.12 and 10.3).

The Cement Association of Japan, Hattori Building No. 1, 1-chome, Kyobashi, Chuo-ku, Tokyo, Japan (Figures 3.13, 4.2 , 4.11, 4.17, 4.20, 5.3, 5.7, 5.8, 5.11, 5.12, 5.20 and 5.22).

Cement and Concrete Association, Wexham Springs, Slough, SL3 6PL, UK (Figures 3.10, 5.25 to 5.27, 5.32, 8.3, 8.4, 8.6, 8.8, 8.24, 9.1, 9.4, 9.6, 9.7, 9.21, 9.22 and 9.27).

Commonwealth Scientific and Industrial Research Organization (CSIRO), 372 Albert St, East Melbourne, Victoria 3002, Australia (Figures 2.8, 2.10 and 5.12).

Edward Arnold (Publishers) Ltd, 25 Hill St, London W1X 8LL, UK (Figures 1.1 and 1.2).

EMPA, CH-8600, Dübendorf/ZH, Switzerland (Figures 5.9, 5.10 and 7.11).

The Engineering Institute of Canada, 700 E.I.C. Building, 2050 Mansfield St, Montreal, Quebec H3A 1Y9, Canada (Figures 3.14, 4.24, 5.4 and 5.5).

National Bureau of Standards (NBS), United States Department of Commerce, Washington, DC 20234, USA (Figures 6.8, 7.1, 7.2, 9.15 and 10.5).

National Research Council (NRC), Division of Building Research (DBR), Montreal Road, Ottawa K1A OR6, Canada (Figures 3.11 to 3.14, 4.24, 5.4, 5.5, 5.20 and 5.22).

National Research Council, Transportation Research Board, 2101 Constitution Avenue, Washington, DC 20418, USA (Figures 2.3, 3.16, 5.2, 5.33, 6.6, 6.7 and 11.6).

Portland Cement Association (PCA), Old Orchard Road, Skokie, Illinois 60076, USA (Figures 4.10, 4.11, 4.18, 4.20, 5.3, 5.7, 5.11, 5.13, 6.4, 6.11, 10.1 and 10.2).

Reologica Acta, Dr Dietrich Steinkoptf Verlag, 6100 Darmstadt, Saalbaustrasse 12, West Germany (Figures 5.30 and 5.31).

RILEM and Dunod Editor, 12 Rue Brancion, 75737 Paris Cedex 15, France (Figures 3.11, 3.12, 3.15, 5.19, 5.29, 5.34, 8.19, 9.10 and 9.13).

Swedish Cement and Concrete Institute, Royal Institute of Technology, Fack S100, 44 Stockholm 70, Sweden (Figures 4.21 and 11.16).

Technical Research Centre of Finland, Vuorimiehentie 5, 02150 Espoo 15, Finland (Figure 5.28). 
University of Toronto Press, University of Toronto, Toronto M5S IA6, Canada (Figures 7.7, 10.1 and 10.2).

Zement-Kalk-Gips, Bauverlag GmbH, 6200 Wiesbaden, Wittelsbacherstrasse 10, West Germany (Figures 2.9, 4.16 and 4.19).

The author is also grateful to the authors of the papers from which the figures and tables were reproduced. Direct reference to these authors is made in the appropriate captions. 